\title{
Sistem MPPT Pengisian Baterai dengan Solar Cell untuk Mobil Listrik
}

\author{
Chris Septiyan ${ }^{1}$, Ta'ali² \\ ${ }^{1}$ Universitas Negeri Padang \\ Jl. Prof Dr. Hamka Air Tawar, Padang \\ chrisseptiyan@gmail.com, taali_mt@yahoo..co.id
}

\begin{abstract}
Solar panels are an efficient and environmentally friendly source of direct current (dc) electrical energy. The working principle of solar panels is bypassing the photoelectric effect where certain materials create an electric current in sunlight, resulting in direct current and can be connected to DC electrical equipment, one of which is to charge DC batteries, but the output power of solar panels varies and is not maximum. because the level of solar irradiation is unstable, thus charging a dc battery is unstable. This study aims to obtain the maximum power output of solar panels using solar panel tracker control, namely the expected maximum power point tracker (MPPT) and a dc-dc converter is needed. This research consisted of making a buck dc-dc converter that can reduce direct current voltage, current sensor, voltage sensor and MPPT system using Arduino uno controller and system coding. The experimental results show that all components and system devices are able to work according to the research objectives. By using a buck converter and MPPT control system, the solar panel output power will be maximum.
\end{abstract}

Keywords - Solar Panel, converter dc-dc, maximum power point tracker (MPPT).

Abstrak- Solar panel merupakan sumber energi listrik arus searah atau direct current (dc) yang efisien dan ramah lingkungan. Prinsip kerja solar panel yaitu melewati efek fotolistrik dimana bahan-bahan tertentu menciptakan aliran listrik pada cahaya matahari, sehingga menghasilkan arus searah dan dapat dihubungkan ke peralatan listrik dc salah satu nya, untuk pengisian baterai dc akan tetapi daya keluaran solar panel yang bervariasi dan tidak maximum dikarenakan tingkat penyinaran matahari tidak stabil dengan demikian pengisian baterai dc tidak stabil. Penelitian ini bertujuan agar mendapatkan keluaran daya solar panel yang maximum mengunakan pengontrolan tracker panel surya yaitu maximum power point tracker (MPPT) yang diharapkan serta diperlukan konverter dc-dc. Penelitian ini terdiri dari pembuatan konverter dc-dc buck yang dapat menurunkan tegangan arus searah, sensor arus, sensor tegangan dan sistem MPPT menggunakan pengendali Arduino uno serta pengkodean sistem. Hasil percobaan menunjukan semua komponen dan perangkat sistem mampu bekerja sesuai tujuan penelitian. Dengan menggunakan konverter buck dan sistem pengontrolan MPPT, maka daya keluaran solar panel akan maximum.

Kata kunci-solar panel, konverter dc-dc, maximum power point tracker (MPPT).

\section{Pendahuluan}

Prinsip kerja solar cell yaitu melewati efek fotolistrik dimana bahan-bahan tertentu menciptakan aliran listrik saat matahari bersinar di atasnya. Panel surya sendiri terdiri dari kristal silikon di mana setiap setengah didopin menjadi dopan yang berbeda untuk menghasilkan sebuah semikonduktor. Ketika matahari muncul di permukaan, panel surya menyediakan energi yang dibutuhkan untuk semikonduktor dan menghasilkan arus searah (DC) [2].Pengisian baterai maksimal yaitu 1 WP terjadi pada kisaran pukul 10.00 - 14.00 sedangkan puncak tertinggi kisaran 11.00 - 13.00 khususnya waktu indonesia bagian barat (WIB), misalkan 08.00 WIB dan 16.00 WIB solar cell hanya menyerap $1 / 2 \mathrm{Wp}, 1 / 4 \mathrm{WP}$ atau tidak maksimal, sehingga secara teori rangkaian listrik terjadi keterbalikan rangkaian yaitu solar cell tidak melakukan proses pengisian baterai, akan tetapi menyerap energi listrik di baterai karena perbeda potensi solar cell lebih kecil dari baterai[3]. Penyinaran matahari yang tidak stabil mempengaruhi daya keluaran solar panel yang tidak maksimum dan tidak stabil sehingga diperlukan konverter dc-dc buck bertujuan menurunkan tegangan dc serta dibutuhkan pengontrolan tracker panel surya yaitu maximum power point tracker (MPPT) yang dikendalikan oleh arduino uno yang bertujuan dapat memaksimumkan daya keluaran panel surya seperti tujuan yang diharapkan[4]. Adapun manfaat penelitian yaitu diantaranya menurunkan ketergantungan kita akan pengunaan bahan bakar fosil yang tidak dapat diperbaharui dan bahaya gas hasil pembakaran, meningkatkan pengunaan sumber energi terbaru dan efesiensi seperti panel surya serta memaksimumkan daya keluaran panel surya mengunakan metode sistem MPPT. 


\section{METODE}

Metode yang digunakan dalam penelitian ini adalah membuat perangkat hardware sistem otomatisasi pada penggontrolan tracker panel surya diantaranya Maximum Power Point Tracker (MPPT) hingga pelaksanaan percobaan pengujian pada masing-masing komponen.

\section{A. Panel Surya}

Panel surya adalah alat yang terdiri dari sel surya yang mengubah cahaya menjadi listrik. Pada umumnya, solar cell merupakan sebuah hamparan semi konduktor yang dapat menyerap photon dari sinar matahari dan mengubahnya menjadi listrik.

Panel surya sering kali disebut sel photovoltaic, photovoltaic dapat diartikan sebagai "cahaya listrik" Sel surya bergantung pada efek photovoltaic untuk menyerap energi. Photo merujuk kepada cahaya dan voltaic merujuk kepada tegangan. Terminologi ini digunakan untuk menjelaskan sel elektronik yang memproduksi energi listrik arus searah dari energi radian matahari. Photovoltaic cell dibuat dari material semikonduktor terutama silikon yang dilapisi oleh bahan tambahan khusus.(Hafelzan Enang Edovidata, 2020:58). Foto Solar Cell dapat dilihat pada gambar 1.

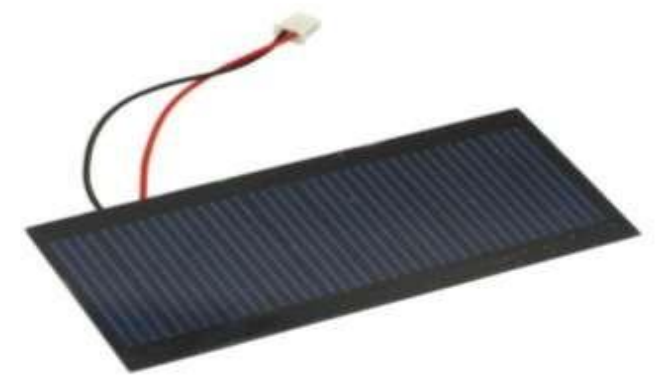

Gambar 1. Solar Cell

\section{B. PWM (Pulse Width Modulation)}

$P W M$ merupakan teknik memanipulasi lebar sinyal yang dinyatakan dengan pulsa dalam suatu perioda, Amplitudo sinyal asli yang belum termodulasi berbanding lurus dengan lebar pulsa PWM. Artinya, duty cycle bervariasi (antara 0\% sampai 100\%) sedangan sinyal PWM memiliki frekuensi gelombang yang konstan seperti pada gambar2.

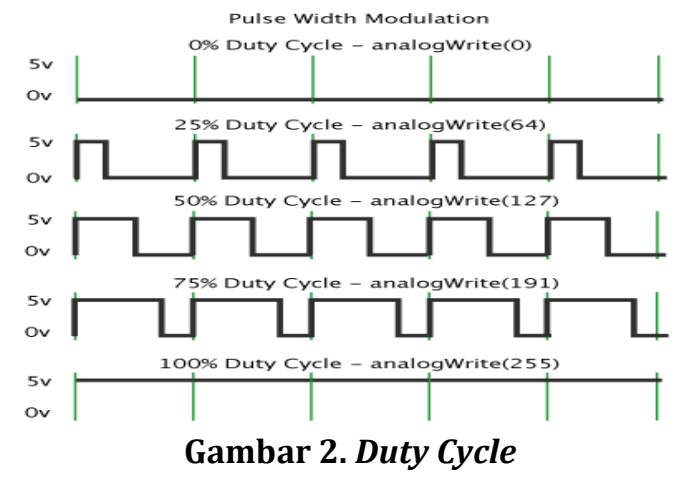

\section{Catu Daya}

Rangkaian ini berfungsi untuk penurunan tegangan dari sumber sebesar 220 volt AC menjadi tegangan, 6 Volt, 9 Volt, 12 Volt dan 24 Volt pada bagian sekundernya. Peran transformator step down sebagai penurun tegangan dengan dibantu oleh rangkaian penyearah gelombang yang mana nantinya rangkaian ini akan mengubah tegangan volt AC menjadi volt DC. Rangkaian catu daya dipasangkan juga beberapa kapasitor bertujuan meratakan riak tersebut dan memberikan suatu tegangan DC yang hampir murni, biasanya kapasitor filter. Kapasitior filter memiliki nilai yang besar, lalu penstabil atau regulator, contoh dari penstabil adalah rangkaian terpadu dengan tipe IC 7805, 7905, 78012, 7912 dan lainnya.

\section{Arduino Uno}

Arduino adalah pengendali mikro single-board yang bersifat open-source, diturunkan dari Wiring platform, dirancang untuk memudahkan penggunaan elektronik dalam berbagai bidang. Hardwarenya memiliki prosesor Atmel AVR dan softwarenya memiliki bahasa pemrograman sendiri. Arduino dilengkapi dengan library C/ C++. Bentuk fisik arduino uno dapat dilihat pada gambar 3 .

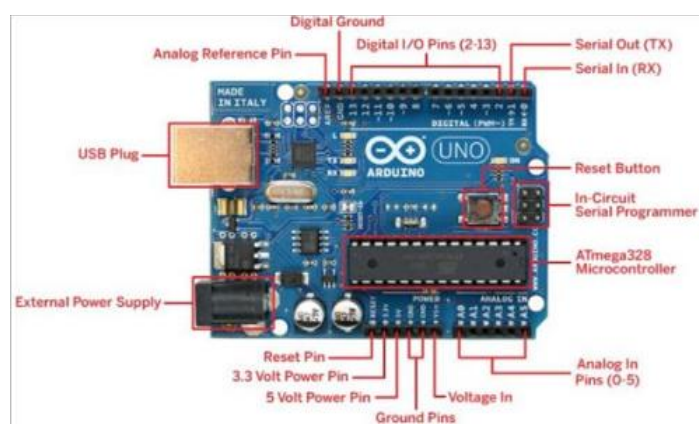

Gambar 3. Arduino Uno

Setiap pin digital pada board arduino uno dapat digunakan sebagai input-output. Dengan menggunakan fungsi pin Mode(), digitalWrite(), dan digitalRead() yang akan beroperasi pada tegangan $5 \mathrm{~V}$. Setiap pin mampu memberi atau menerima maksimum $40 \mathrm{~mA}$ dan memiliki resistor pull-up internal $20-50 \mathrm{~K} \mathrm{ohm}$. Selain itu ada beberapa pin memiliki fungsi khusus. Serta mempunyai flash memori $32 \mathrm{~KB}$ dengan $0.5 \mathrm{~KB}$ digunakan untuk bootloader, 2KB SRAM dan $1 \mathrm{~KB}$ EEPROM, berikut blok memori arduino uno seperti pada gambar 4. 


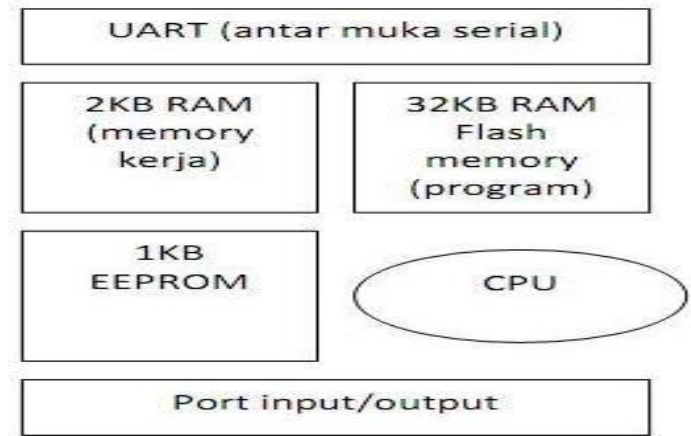

\section{Gambar 4. Diagram Blok Memori Arduino Uno}

\section{E. Buck Converter}

Konverter DC-DC digunakan untuk mengubah sumber tegangan dc menjadi sumber tegangan dc yang bersifat variabel. Seperti transformator, DC-DC Konverter dapat digunakan untuk menaikkan dan menurunkan sumber tegangan dc, dan merupakan rangkaian elektronika daya yang digunakan untuk mengubah tegangan masukan searah yang konstan menjadi tegangan keluaran searah yang bisa divariasikan. Untuk memvariasikan tegangan kelaran yaitu sesuai dengan duty cycle dari control.

\section{F. Sensor Arus}

Penggunaan sensor arus sendiri bertujuan mengetahui arus AC atau DC berbagai bidang di industri. Kebanyakan digunakan untuk mengontrol motor, deteksi beban listrik, dan proteksi beban berlebih. Sensor arus yang dipakai untuk pembuatan tugas akhir ini bertipe ACS712, bentuk rangkaian sensor arus ACS712 dapat dilihat pada gambar 5 .

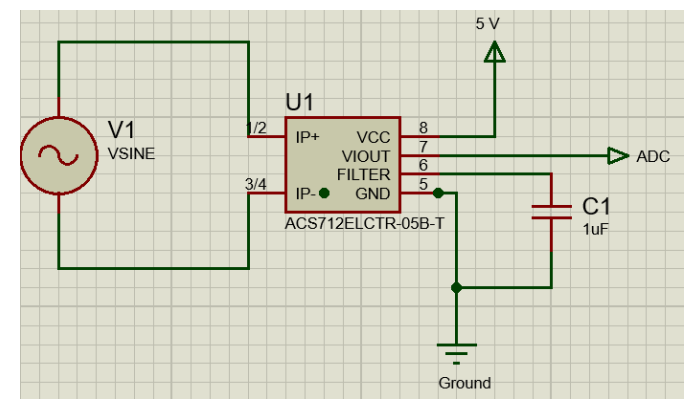

Gambar 5. Sensor Arus ACS712

\section{G. Sensor Tegangan}

Sensor tegangan ini terdiri dari dua buah resistor, aturan pembagi tegangannya yaitu tegangan input dibagi secara proporsional sesuai dengan nilai resistensi dua resistor yang dirangkai seri, bentuk rangkaian sensor tegangan dapat dilihat pada gambar 6 .

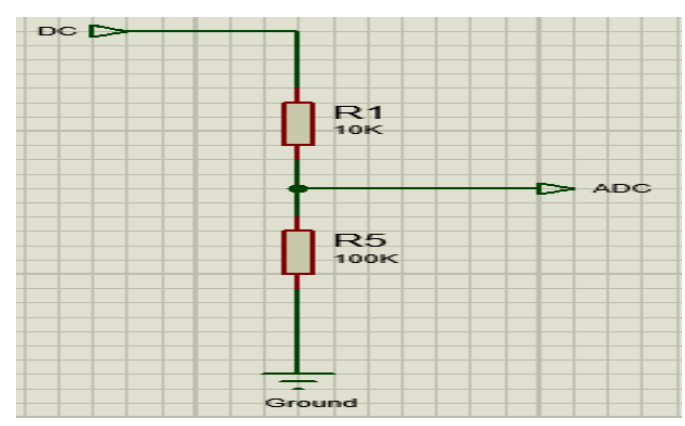

\section{Gambar 6. Sensor Tegangan}

\section{H. Flowchart dan Diagram Blok}

Flowchart merupakan diagram alir yang mengilustrasikan alur atau proses kerja dari suatu sistem.bentuk Flowchart kerja system dapat dilihat pada gambar 7.

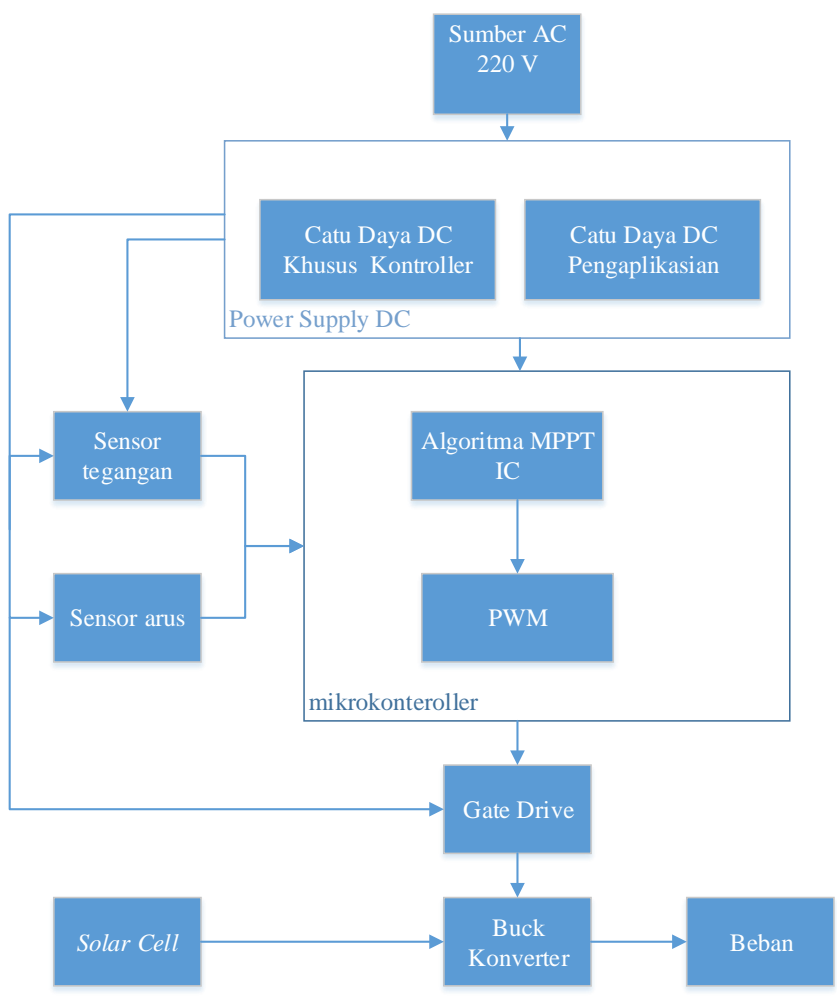

Gambar 7. Flowchart Kerja Sistem 


\section{HASIL DAN PEMBAHASAN}

Pada bagian ini dilakukan pegujian dan pembahasan untuk seluruh bagian input dan output. Pengujian dan pembahasan dilakukan untuk mengetahui sistem catu daya, konverter dc-dc buck, rangkaian gate drive dan panel surya serta komponen lainnya.

\section{A. Instrumen Pengujian Alat}

1. Pengujian Rangkaian Catu Daya

Hasil pengujian dan pengukuran pada catu daya 5 volt Tegangan AC 220 volt dari jala-jala, diturunkan melalui trafo step down. Tegangan AC tersebut kemudian disearahkan dengan penyearah jembatan dioda dan ditapis oleh kapasitor untuk memperkecil riak (noise) agar mendapatkan tegangan yang baik. Data hasil pengujian rangkaian catu daya dapat dilihat pada table I.

\section{Tabel I. Pengujian Rangkaian Catu Daya}

\begin{tabular}{|c|c|c|c|}
\hline Ket. & $\begin{array}{c}\text { Input } \\
\text { Tegangan } \\
\text { AC }\end{array}$ & $\begin{array}{c}\text { Trafo (AC - } \\
\text { AC) }\end{array}$ & $\begin{array}{c}\text { Output } \\
\text { Converter } \\
\text { (AC - DC) }\end{array}$ \\
\hline $\begin{array}{c}\text { Catu } \\
\text { Daya1 } \\
\text { Trafo 3A) }\end{array}$ & 229.4 & $18.46 \mathrm{~V}$ & $11.49 \mathrm{VDC}$ \\
\cline { 2 - 4 } & 229.4 & $18.46 \mathrm{~V}$ & $4.46 \mathrm{VDC}$ \\
\hline $\begin{array}{c}\text { Catu } \\
\text { Daya2 } \\
\text { Trafo 2A) }\end{array}$ & 229.4 & $16.35 \mathrm{~V}$ & 11.62 VDC \\
\hline
\end{tabular}

2. Pengujian Rangkaian Gate Drive

Gate drive pada MPPT ini berfungsi sebagai interface antara mosfet dan mikrokontroller. Data pengujuan rangkaian gate drive dapat dilihat pada tabel II.

Tabel II. Pengujian Rangkaian Gate Drive

\begin{tabular}{|c|c|c|c|}
\hline No & Vin (gate Drive) & $\begin{array}{c}\text { Duty Cycle } \\
\text { (\%) }\end{array}$ & $\begin{array}{c}\text { Vout } \\
\text { (Vdc) } \\
\text { Gate } \\
\text { Drive } \\
\end{array}$ \\
\hline 1 & \multirow[t]{5}{*}{$5 \mathrm{Vdc}$} & 20 & 2.76 \\
\hline 2 & & 40 & 5.53 \\
\hline 3 & & 60 & 8.33 \\
\hline 4 & & 80 & 11.20 \\
\hline 5 & & 100 & 13.26 \\
\hline
\end{tabular}

3. Pengujian Rangkaian Konverter Buck

Dalam pengujian rangkaian converter buck ini dilakukan dengan memberikan tegangan pada sisi input rangkaian konverter buck, tegangan yang diberikan yaitu berupa perubahan duty cycle dan kemampuan alat untuk menahan besar tegangan yang diberikan. Duty cycle yang bervariasi diantaranya yaitu $50 \%$ - 20\%. Data hasil pengujuan rangkaian konverter buck dapat dilihat pada table III.
Tabel III. Pengujian Rangkaian Konverter Buck

\begin{tabular}{|c|c|c|}
\hline $\begin{array}{c}\text { PWM } \\
(\%)\end{array}$ & Solar cell & Vout (V) \\
\cline { 2 - 3 } & Vin (V) & \\
\hline 50 & $19-20$ & 15.10 \\
\hline 40 & $19-20$ & 14.90 \\
\hline 30 & $19-20$ & 14.40 \\
\hline 20 & $19-20$ & 14.05 \\
\hline
\end{tabular}

4. Pengujian Panel Surya

Dalam pengujian panel surya ini dilakukan dengan menghubungkan panel surya dengan alat ukur dan rangkaian keseluruhan. Data hasil pengujian panel surya dapat dilihat pada tabel IV.

Table IV. Pengujian Panel Surya

\begin{tabular}{|l|l|l|l|c|}
\hline No & \multirow{2}{*}{$\begin{array}{l}\text { Waktu } \\
\text { (WIB) }\end{array}$} & $\begin{array}{c}\text { Tanpa } \\
\text { beban }\end{array}$ & Berbeban & $\begin{array}{c}\text { Intensitas } \\
\text { caahaya } \\
\text { matahari } \\
\text { (Lux) }\end{array}$ \\
\hline 1 & 07.40 & 18,76 & 12,40 & 14550 \\
\hline 2 & 08.00 & 19,20 & 12,93 & 21000 \\
\hline 3 & 09.00 & 18,79 & 13,55 & $>50000$ \\
\hline 4 & 10.00 & 18,90 & 13,50 & 44300 \\
\hline 5 & 11.00 & 18,81 & 13,81 & $>50000$ \\
\hline 6 & 12.00 & 18,90 & 13,83 & $>50000$ \\
\hline 7 & 13.00 & 18.92 & 13,90 & $>50000$ \\
\hline 8 & 14.00 & 18,94 & 13,94 & 45300 \\
\hline
\end{tabular}

\section{PENUTUP}

Berdasarkan hasil pengujian dapat disimpulkan bahwa pergeseran posisi matahari ke arah belahan bumi utara dan selatan disebut gerak semu harian matahari,disebut demikian karena sebenarnya matahari tidah bergerak, gerakan terjadi akibat revolusi bumi dengan sumbu rotasi yang miring sehingga mempengaruhi posisi letak solar cell ke matahari dan mempengaruhi tegangan keluran solar cell.

Perputaran bumi terhadap matahari disebut rotasi bumi mempengaruhi posisi letak solar cell ke matahari dan tegangan keluaran solar cell tiap jam nya.Perhitungan titik azimuth dan elevasi mempengaruhi posisi letak solar cell ke matahari.Pengunaan solar cell 50 WP dengan solar cell 20 WP memliki keluran tegangan yang berbeda.

Metode Sistem MPPT yang digunakan mampu mencari titik daya maksimum dari solar cell karena input yang dipakai adalah tegangan dan arus input dengan umpan balik tegangan keluaran yang dihasilkan. 


\section{REFERENSI}

[1] Andrianto, Heri. 2016. Arduino( Belajar Cepat dan Pemrograman). Informatika Bandung: Bandung.

[2] Aswardi. 2010. Modul Elektronika Daya. Padang : Universitas Negeri Padang.

[3] Elsi Martha (2018)." Perancangan Sistem Pengisian Accumulator Mobil Listrik Dengan Sumber Solar Cell. Padang. Universitas Negeri Padang.

[4] Ernadi, Dwiyan anugrah. 2016. Desain Maximum Power Point Tracking untuk Turbin Angin Menggunakan Modified Perturb \& Observe (P\&O) Berdasarkan Prediksi Kecepatan Angin.Jurnal Teknik ITS Vol.5, No. 2.

[5] Hafelzan Enang Edovidata, Aswardi. 2020. Perancangan Sistem Pengisian Accumulator Mobil Listrik dengan Sumber Listrik Solar Cell Berbasis Mikrokontroler. JTEV, 6(1), 58.

[6] K Ogata, Modern Control Systems, University of Minnesota, Prentice Hall, 1987.

[7] Rashid, Muhammad H. (2011). Power Electronics Circuit Device and Applications $3^{\text {rd }}$ Edition. Purdue University at Fort Wayne Indiana.

[8] F. R. Nurlianisa, "Kit Aquascape Berbasis Internet of Things Melalui Aplikasi Blynk dengan Arduino Uno Untuk Pemeliharaan Lilaeopsis Brasiliensis," 2018.

\section{Biodata Penulis}

Chris Septiyan, lahir di Padang, 15 September 1994. Menyelesaikan studi DIV Teknik Elektro Industri pada Jurusan Teknik Elektro Fakultas Teknik Universitas Negeri Padang.

Ta'ali, lahir di Pekalongan, 16 Oktober 1963. Menyelesaikan studi S1 di IKIP Padang tahun 1989. Pendidikan S2 di Institut Tekneologi Bandung tahun 1999. Pendidikan S3 di Universitas Negeri Yogyakarta tahun 2017 Staf pengajar pada jurusan teknik elektro FT UNP sejak tahun 2006 sampai sekarang. 